\title{
INFLUENCE OF CAPITAL EXTRACT ON OFFSHORE ZONES ON UKRAINE'S ECONOMY
}

\author{
Makazan Ye. V., Veremeyenko O. O. \\ Zaporizhzhia National University \\ Ukraine, 69600, Zaporizhzhia, Zhukovsky str., 66 \\ e.v.makazan@gmail.com, veremeenko1711@meta.ua \\ ORCID 0000-0001-5855-0476, ORCID 0000-0003-0014-1615
}

\section{Key words:}

energy efficiency, policy, design, principles, energy saving, enterprise, activity, concept.
The principles of energy saving policy are considered, which will help to implement an active policy of energy efficiency improvement. It is established that the introduction of the principles of energy saving policy in the activities of domestic enterprises will help increase their energy efficiency, which, in turn, is a major factor in improving the efficiency of production activities. The main objectives of energy efficiency policy at the macro and macro levels are highlighted. The list of concrete functions of management of process of energy saving at the enterprise is given. The components of energy efficiency design are singled out. The main measures in the field of energy saving at enterprises are identified. It is established that the goals of energy saving policy are global in nature and are determined by current trends in energy development, namely: energy supply (provision of quality energy resources under conditions of their uninterrupted supply), energy availability (energy resources must have a market-based price). on ecology). It is established that the policy should be based on the results of economic and energy surveys of all production and non-production units. Currently, the main factor in shaping the energy efficiency of machine-building enterprises is the creation of an effective system for improving energy efficiency.

\section{ТЕОРЕТИЧНІ ЗАСАДИ ВИКОРИСТАННЯ ЕНЕРГОЕФЕКТИВНОСТІ ПІДПРИСМСТВ МАШИНОБУДУВАННЯ}

\author{
Маказан С. В., Веремсснко О. О. \\ Запорізький національний університет \\ Україна, 69000, м. Запоріжжя, вул. Жуковського, 66
}

\begin{abstract}
Ключові слова:
енергоефективність, політика, проектування, принципи, енергозбереження, підприємство, діяльність, концепція.
\end{abstract}

Розглянуто принципи енергозберігаючої політики, які допоможуть реалізувати активну політику підвищення енергоефективності. Встановлено, що упровадження принципів енергозберігаючої політики в діяльність вітчизняних підприємства буде сприяти підвищенню їх енергоефективності, що, своєю чергою, $\epsilon$ основним фактором підвищення ефективності виробничої діяльності. Виділено основні завдання політики підвищення енергоефективності на макро- та макрорівнях. Надано перелік конкретних функцій управління процесом енергозбереження на підприємстві. Виокремлено складові проектування енергоефективності. Визначено основні заходи у сфері енергозбереження на підприємствах. Встановлено, що цілі енергозберігаючої політики носять глобальний характер та визначаються сучасними тенденціями розвитку енергетики, а саме: енергозабезпеченням (наданням якісних енергоресурсів за умов їх безперебійного постачання), енергодоступністю (енергоресурси повинні мати ринково обгрунтовану ціну за умов енергоощадливості споживачів), енергоприйнятністю (забезпеченням мінімального впливу на екологію). Встановлено, що проведення політики повинно грунтуватися на результатах економіко-енергетичного обстеження всіх виробничих і невиробничих ланок. Нині основним фактором формування енергоефективності підприємств машинобудування $є$ створення ефективно діючої системи підвищення енергоефективності.

\section{Statement of the problem}

At the beginning of the XXI century formed a modern vision of the mission of world energy. It consists in the most efficient use of natural fuel and energy resources (FER) and the potential of the energy sector for the growth of the world economy, increasing its potential and improving the quality of life of the world's population. In this regard, today in the leading countries is the formation of a new energy civilization, the main features of which are energy efficiency; intelligent energy systems built according to the Smart Grid concept; decentralization of energy; new energy sources. For Ukraine, the problem of inefficient consumption of energy resources by all types of consumers is at the forefront of a number of priority solutions, as low energy efficiency is a key factor in the negative impact on the political stability and national security of our country.

\section{Analysis of recent research and publications}

Energy saving and energy efficiency are given a lot of attention by domestic economists. Yes, O.S. Gordienko 
[8] believes that energy saving is «a process in which the need for energy resources is reduced per unit of final beneficial effect from their use.»

O. G. Kosheva notes that «energy conservation is the process of rational use of energy resources and the involvement of renewable energy sources to ensure energy efficiency of economic development and improve the social situation in the country, as well as preserving the ecosystem and non-renewable energy sources for future generations» [9].

V. M. Timofeev and I. A. Nemirovsky believes that «energy saving is one of the components of energy management as a practical aspect of its activities, which uses advanced technologies and equipment", while, in their opinion, the concept of "energy management" is much broader and includes, in addition to energy saving, the use of non-traditional and renewable energy sources, the development of pricing policy, the rules of the game in the energy market, which meet primarily the interests of the state, and then the interests of business» [10, p. 33].

According to B. V. Gaprindashvili [2], energy saving is «a set of organizational, scientific, economic, environmental and technological actions aimed at rational and safe use of energy and natural resources in the national economy to reduce costs during production, services and to achieve the ultimate social economic effects of their use».

K. I. Dokunina [11] gives the following definition: «Energy saving is a set of defined and consistent actions, as a result of which a positive (economic) result of the use of energy resources is achieved».

Authors of the work [12, p. 24] believe that «energy saving is the efficient use of energy by consumers, including the minimization of energy consumption per unit of output».

Thus, the analysis of scientific research shows that there are different approaches to defining this concept:

- energy saving as an activity;

- energy saving as an integral part of management;

- energy saving as a process;

- energy saving as a result.

Summarizing the above definitions, we can conclude that, despite different approaches, most researchers directly or indirectly equate the concept of «energy saving» with energy efficiency, which is possible only if each company organizes efficient energy saving activities.

\section{Aim of research}

The principles of energy efficiency policy reveal to, the concept of energy efficiency policy build to.

\section{Results of research}

Energy saving activities at machine-building enterprises are carried out within the framework of energy efficiency improvement policy. Policy implementation should be based on the results of economic and energy surveys of all production and non-production units. Currently, the main factor in shaping the energy efficiency of machinebuilding enterprises is the creation of an effective system for improving energy efficiency. This system must have technical and organizational and economic components.
The technical component is based on increasing production efficiency and reducing energy intensity of products through the introduction of energy saving measures, alternative energy sources, the latest production technologies, reducing energy losses, energy replacement.

The organizational and economic component is based on the formation of the company's energy management services, whose activities are aimed at ensuring the rational use of fuel and energy resources and is based on obtaining energy information through accounting, standard energy technology measurement and verification and analysis of fuel and energy efficiency. and implementation of energy saving measures [13, p. 5].

An energy efficiency policy cannot exist without designing an energy efficiency system consisting of the following components: the subject of the design; design tasks; design parameters; source documentation; design result.

The subject of design is the formalization of procedures to improve energy efficiency; creation of structures and typification of energy efficiency processes; models, methods and algorithm for forming energy efficiency measures.

Design parameters - information about existing technologies, production capacity, the company's prospects in the market.

Initial documentation of the project: methods and tools for diagnosing the level of energy efficiency of the enterprise, algorithms for obtaining and processing data, monitoring; description of energy efficiency tools used, methods of their application; instructions for personnel to ensure energy efficiency measures; description of the results of the use of energy efficiency tools and ways to adjust their use; control examples and tests; cost and procedure for implementing the energy efficiency system.

In turn, the components of energy efficiency systems depend on intersectoral and intra-industry shifts in the country's economy. According to the Energy Strategy of Ukraine for the period up to 2030, the projected energy saving potential of the country in 2030 will be 318.4 million tons, which is almost one and a half times the current level of primary energy consumption. Implementation of technological and structural energy supply measures will allow reduce to the level of energy consumption by $51.3 \%$ in 2030 - from 621 million tons. $\mathrm{n}$. at the current level of energy efficiency up to 302.7 million tons item at the predicted level [14, p. 96].

However, energy efficiency policies should not be equated only with the task of reducing energy costs. Its goals are more global and are determined by current trends in energy development, namely: energy supply (provision of quality energy resources under conditions of their uninterrupted supply), energy availability (energy resources must have a market-based price in terms of energy efficiency of consumers), energy efficiency.

Thus, at the microeconomic level, the following main objectives of energy efficiency policy can be identified [15]:

- ensuring the growth of production efficiency and expanding the volume and range of products as a result of 
the introduction of energy-efficient machinery and equipment;

- Definition, economic evaluation, development and implementation of energy saving measures;

- creating a picture of energy consumption and analysis of energy use to identify potential opportunities for its savings and, as a result, reduce the cost of finished products;

- Reduction of the negative impact of production and use of energy resources on the environment.

The list of specific functions of energy saving process management at the enterprise can be as follows [4, p. 410]:

1. Determination of energy consumption for each type of product; identification of reserves to increase the efficiency of energy resources; analysis of the possibilities of using energy-saving technologies and equipment.
2. Formation of target parameters of energy saving.

3. Development of measures to reduce energy consumption at the enterprise; calculation of options for the need for energy resources depending on possible changes.

4. Involvement of employees of all levels in the process of energy saving at the enterprise.

5. Ensuring support for the proposed changes. 6 . Development and implementation of a system of material incentives for increasing the level of energy saving at the enterprise.

6. Introduction and constant check of key indicators of efficiency of process of increase of energy efficiency at the enterprise.

The implementation of an active policy of energy efficiency should be based on the following principles (Table 1) [16, p. 32].

Table 1 - Principles of energy saving policy

\begin{tabular}{|c|c|}
\hline Principle & The content of the principle \\
\hline $\begin{array}{l}\text { The principle of priority of the } \\
\text { purpose of the power system }\end{array}$ & $\begin{array}{l}\text { The purpose of the power system is the production of products (services) with } \\
\text { minimal specific energy consumption }\end{array}$ \\
\hline The principle of systematization & $\begin{array}{l}\text { It consists in the coherence of the activities of all subjects of management (energy } \\
\text { saving should be carried out at all levels) and in the fact that the energy saving } \\
\text { system is a subsystem of the production management system }\end{array}$ \\
\hline The principle of complexity & $\begin{array}{l}\text { Existence of a system of measures (technical-technological, organizational- } \\
\text { economic, socio-psychological, etc.) aimed at energy savings }\end{array}$ \\
\hline $\begin{array}{l}\text { The principle of completeness of } \\
\text { energy needs }\end{array}$ & $\begin{array}{l}\text { Production should be provided with energy resources in such quantities that the } \\
\text { energy factor at least limits the volume of production. It is possible to compensate } \\
\text { the lack of direct energy due to its partially past costs in other industries, the } \\
\text { products of which are consumed in the production process. }\end{array}$ \\
\hline $\begin{array}{l}\text { The principle of efficient } \\
\text { distribution of energy resources }\end{array}$ & $\begin{array}{l}\text { Insufficient energy resources should be allocated to alternative areas so that the } \\
\text { cost of production growth during the use of the last unit of energy resources in } \\
\text { each of the areas was the same }\end{array}$ \\
\hline $\begin{array}{l}\text { The principle of maximizing } \\
\text { energy efficiency of production }\end{array}$ & $\begin{array}{l}\text { The planning of the production structure should be carried out taking into account } \\
\text { the specific energy consumption. It is possible to reduce energy consumption of } \\
\text { production at the expense of the structural shifts directed on optimization of } \\
\text { volumes of manufacture of production on criterion of energy efficiency }\end{array}$ \\
\hline $\begin{array}{l}\text { The principle of interest of } \\
\text { producers in energy saving }\end{array}$ & $\begin{array}{l}\text { Evaluation of the results of economic entities, the system of incentives for } \\
\text { employees must take into account the consequences of energy consumption, the } \\
\text { level of energy intensity of production }\end{array}$ \\
\hline $\begin{array}{l}\text { The principle of normative energy } \\
\text { consumption }\end{array}$ & $\begin{array}{l}\text { Rational management of production is based on the application of economically } \\
\text { justified norms of energy consumption, which should be progressive (focused on } \\
\text { achieving scientific and technological progress) and differentiated based on } \\
\text { regional and sectoral characteristics }\end{array}$ \\
\hline $\begin{array}{l}\text { The principle of purposefulness of } \\
\text { energy consumption }\end{array}$ & $\begin{array}{l}\text { Is to focus the cost of scarce energy resources in areas where their use will have } \\
\text { the highest return }\end{array}$ \\
\hline $\begin{array}{l}\text { The principle of adequacy of } \\
\text { factors of production and energy } \\
\text { saving }\end{array}$ & $\begin{array}{l}\text { Is the compliance of equipment, technology and production management to the } \\
\text { requirements of improving the energy efficiency of technological processes }\end{array}$ \\
\hline $\begin{array}{l}\text { The principle of systematization } \\
\text { of energy efficiency indicators }\end{array}$ & $\begin{array}{l}\text { Means the application of a system of efficiency indicators in the use of energy } \\
\text { resources and the ability to determine them on the basis of the current system of } \\
\text { accounting and reporting of the enterprise }\end{array}$ \\
\hline
\end{tabular}

The introduction of the principles of energy saving policy in the activities of domestic enterprises will help increase their energy efficiency, which, in turn, is a major factor in improving the efficiency of production activities. Schematically, the policy of energy efficiency can be depicted as follows (Fig. 1) 


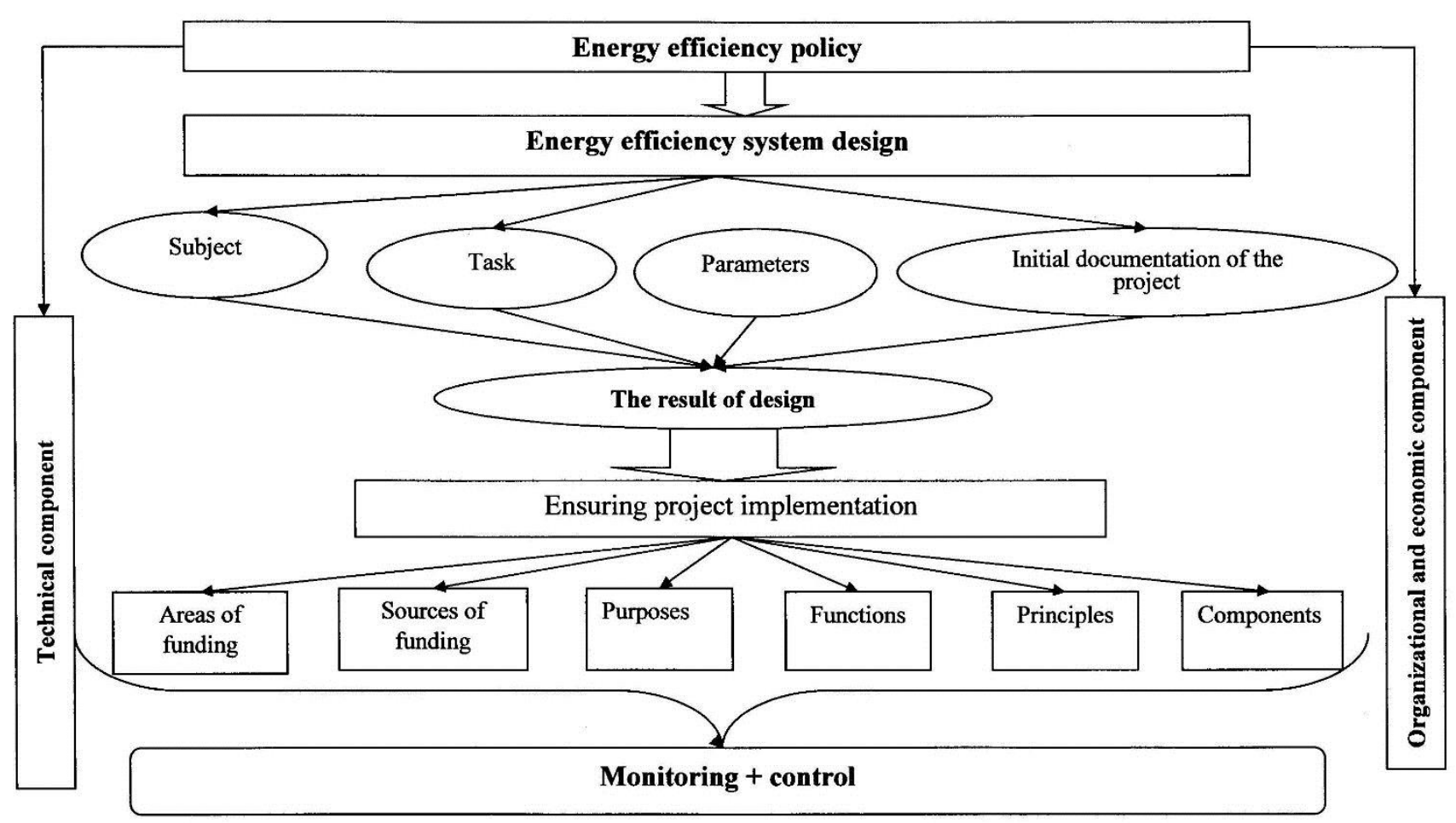

Fig. 1. Policy to increase energy efficiency of machine-building enterprises

Note: built by the author

Efficiency is the achievement of the greatest results at the lowest cost of living and tangible labor, a specific form of saving time. Thus, efficiency is an economic category that reflects the production relations for the saving of living and tangible labor and shows the ultimate beneficial effect of the use of means of production and living labor.

The result of increasing the efficiency of enterprises is, as a rule, increasing productivity, reducing material, energy, capital, labor and wages, increasing the efficiency of capital investment, rational use of natural resources. In turn, among the factors of increasing the efficiency of activities at the place of implementation in the management system of the enterprise, scientists distinguish internal «soft» and «hard» factors, in particular the latter factor «materials and energy».

Production efficiency is a complex economic category, which reflects the degree of use of the mechanism of economic laws and identifies the most important aspect of the enterprise - its effectiveness [17].

Practically increase of efficiency of activity of the enterprise through rational use of fuel and energy resources (FER) is carried out by means of the mechanism of energy saving. Based on the definition of the energy saving mechanism, on the one hand, as an organic component of the enterprise management mechanism, and on the other - as a set of specialized sub-mechanisms operating at the level of specific components of the economic system (production, distribution, consumption), it can be argued that any changes energy saving mechanisms affect the economic system in general and the efficiency of its operation in particular [18].

The economic efficiency of production is affected by rising energy prices, which leads to increased production costs, rational use of energy resources and the use of unconventional and renewable energy sources, which help reduce production costs and the amount of payments for emissions. This allows you to increase production, improve product quality and competitiveness, and reduce energy consumption. Thus, we see that concepts such as «energy saving» and «energy efficiency» are interrelated, as for the most part energy saving is a major factor in improving the efficiency of energy resources.

The concept of energy efficiency is somewhat broader and includes not only areas of direct energy saving, but also indirect measures that lead to a reduction in the consumption of fuel and energy resources. According to the Law of Ukraine «On Energy Conservation», energy efficient products, technology, equipment - is a product or method, means of its production, ensuring the rational use of fuel and energy resources compared to other options for use or production of the same consumer level or similar technical and economic indicators [7].

Energy efficiency is a characteristic of equipment, technology, production or the system as a whole, which indicates the degree of energy use per unit of final product. Energy efficiency is assessed both by quantitative indicators (amount of energy used per unit of final product) and qualitative (low, high) [19].

Energy saving is a set of measures or actions taken to ensure the most efficient use of energy resources, and energy efficiency is the ratio of the actual value of the indicator of energy use to the theoretically achieved. That is, it is a measurable quantity that allows evaluating the result of the process of efficient use of energy.

Considering the definition of «energy saving», we can conclude that the strategic goal of energy saving is to 
increase energy efficiency in all industries and the country as a whole, and the main task - to determine what measures and how much to achieve this increase. Unlike energy saving, which is mainly aimed at reducing energy consumption, energy efficiency is useful, efficient energy consumption. When we talk about energy efficiency, we mean not only energy saving, energy savings in everyday life. It is about the rational and conscious use of energy resources available to everyone for their careful conservation.

To ensure energy saving in enterprises it is necessary to implement [20]:

- Comprehensive application of economic incentives;

- Determination of sources and directions of financing;

- Creation of a base for the implementation of economic measures, the use of a system of state standards in determining the size of economic benefits and the application of economic sanctions;

- Introduction of a fee for irrational use of energy resources;

- Providing subsidies, subsidies, tax, credit and other benefits to legal entities and individuals for stimulating the development, implementation and use of energy-saving technologies.

Energy efficiency in production is achieved with increasing use of existing energy capacity of the enterprise, renewal of fixed assets, effective management, introduction of modern less energy-intensive production technologies, the use of new types of energy and energy sources.

The transition to new energy sources is due to a significant reduction in depleted energy reserves in the world and in Ukraine in particular. Optimal from the standpoint of energy conservation and compliance with energy and, consequently, economic efficiency of production, for enterprises will be the volume of production at which the marginal cost of energy resources for its production is equal to the marginal energy value of output.

This means that in the production process, an increase in energy consumption is justified as long as they do not exceed the value of the energy value of products obtained from their use, which will ensure the competitiveness of enterprise products. Improving energy efficiency at the enterprise increases the income of the enterprise and at the same time brings the following results [5, p. 111]:

- Savings, which ensures the growth of the competitiveness of the enterprise, especially in the case of rising energy prices;

- Increase productivity through the improvement of production processes related to the method of energy use;

- Establishment of emission quotas, which allows to reduce dependence on energy prices, reduce the company's risks, which, in turn, increases the value of the enterprise;

- Reduction of emissions into the environment, which improves the ecological condition, and with it - the image of the enterprise.

The main measures in the field of energy saving in enterprises include [6 p. 109]: the need to account for consumption at the most energy-intensive stages of production; more efficient energy utilization; reduction of reactive power consumption due to installation of compensatory means; improving fuel efficiency; use of various alternative fuels, namely gas and waste; introduction of automatic tools for monitoring, managing the distribution and use of energy in production; control over electricity consumption for lighting, implementation of economical lighting systems; reduction of fuel and heat energy losses due to improved sealing of thermal equipment; repair of thermal insulation with the use of modern thermal insulation materials; introduction of modern temperature control systems; replacement of metal pipes with plastic ones in water, heat and gas supply systems, etc.

\section{Conclusions}

Thus, the problem of energy saving and energy efficiency can be solved only comprehensively by: conducting energy audits to determine energy efficiency and energy saving potential; introduction of energy management system; development of the program of measures for increase of efficiency of energy use, realization of the program; monitoring and confirmation of the effect of the implemented energy saving measure.

\section{References}

1. Afanasyev, M. V. Salashenko, T. I. (2014). Stratehiia pidvyshchennia enerhoefektyvnosti promyslovosti rehionu: teoretyko-metodychni aspekty formuvannia : monohrafiia [Strategy of increasing the energy efficiency of the region's industry: theoretical and methodological aspects of formation: monograph]. Kharkiv: KhNEU [in Ukrainian].

2. Gaprindashvili, B. V. (2014). Enerhozberezhennia yak chynnyk pidvyshchennia konkurentospromozhnosti promyslovykh pidpryiemstv [Energy saving as a factor in increasing the competitiveness of industrial enterprises]. BiznesInform - BusinessInform, 8, 213-217 [in Ukrainian].

3. Gasho, E. G., Stepanova, M. V. Povyshenye enerhoeffektyvnosty kak dvyhatel modernyzatsyy promyshlennosty [Increasing energy efficiency as an engine of industrial modernization]. (n.d.). www.abok.ru. Retrieved from : http://www.abok.ru/for_spec/articles.php?nid=5609 [in Russian].

4. Ippolitova, I. Ya., Sorokotyazhenko, K. S. (2015). Formuvannia orhanizatsiino-ekonomichnoho mekhanizmu enerhozberezhennia na pidpryiemstvi [Formation of organizational and economic mechanism of energy saving at the enterprise]. Hlobalni ta natsionalni problemy ekonomiky - Global and national economic problems, 8, 406-411 [in Ukrainian]. 
5. Maslikevich, M. R., Serdyuk, B. M. (2011). Sutnist otsinky enerhoefektyvnosti pidpryiemstva [The essence of energy efficiency assessment of the enterprise]. Aktualni problemy ekonomiky ta upravlinnia - Actual problems of economy and management, 5, 110-114 [in Ukrainian].

6. Sevastyanov, R. V. (2013). Problemy ta perspektyvy enerhozberezhennia na promyslovykh pidpryiemstvakh [Problems and prospects of energy saving in industrial enterprises]. Teoretychni i praktychni aspekty ekonomiky ta intelektualnoi vlasnosti - Theoretical and practical aspects of economics and intellectual property, 1, 107-110 [in Ukrainian]..

7. Zakon Ukrainy «Pro enerhozberezhennia» [Law of Ukraine "On energy saving]. (n.d.). zakon.rada.gov.ua. Retrieved from: http://www.zakon.rada.gov.ua / go / 74/94 [in Ukrainian].

8. Gordienko, O. S. (2012). Enerhozberezhennia transportnykh pidpryiemstv [Energy saving of transport enterprises]. Tekhnolohycheskyi audyt i rezervy proyzvodstva - Technological audit and production reserves, 1 (7), 13-14 [in Ukrainian].

9. Kosheva, G. O. (2011). Derzhavni mekhanizmy upravlinnia enerhozberezhenniam : avtoref. dys. ... kand. nauk z derzh. uprav. : spets. 25.00.02 «Mekhanizmy derzhavnoho upravlinnia» [State mechanisms of energy saving management: author's ref. dis. ... Cand. Sciences of the state. management : 25.00.02 "Mechanisms of public administration"], Donetsk [in Ukrainian].

10. Timofeev, V. N., Nemirovsky, I. A. (2007). Enerhomenedzhment i enerhosberezhenyia - obshchnost i otlychyia [Energy management and energy saving - commonality and differences]. Enerhosberezhenye. Enerhetyka. Enerhoaudyt - Energy saving. Energy. Energy audit, 5, 32-37 [in Ukrainian].

11. Dokunina, K.I. (2012). Teoretychni aspekty formuvannia ekonomichnoho mekhanizmu enerhozberezhennia [Theoretical aspects of the formation of the economic mechanism of energy saving]. Komunalne hospodarstvo mist Municipal utilities, 106, 341-350 [in Ukrainian].

12. Mikhailov, S.A., Meshalkin, V.P., Balyabina, A.A. (2009). Mesto stratehyy enerhosberezhenyia v stratehyy sotsyalnoekonomycheskoho razvytyia rehyona [The place of energy saving strategy in the strategy of socio-economic development of the region]. Menedzhment v Rossyy y za rubezhom - Management in Russia and abroad, № 2, 22-30 [in Russian].

13. Enerhozberezhennia. Systemy enerhetychnoho menedzhmentu promyslovykh pidpryiemstv. Zahalni vymohy: DST4472:2008 [Energy saving. Energy management systems of industrial enterprises. General requirements: DST4472 2008]. Kiev : Derzhspozhivstandart of Ukraine, 2006, 20 [in Ukrainian]..

14. Enerhetychna stratehiia Ukrainy do 2030 r. [Energy strategy of Ukraine until 2030]. (n.d.). www.aes-ukraine.com. Retrieved from : www.aes-ukraine. com / documents / 5390.html - 48k [in Ukrainian].

15. Voznyuk, M. A. (2013). Problemni aspekty upravlinnia protsesamy enerhozberezhennia na rehionalnomu rivni [Problem aspects of energy saving process management at the regional level]. Finansovo-kredytna diialnist: problemy teorii ta praktyky - Financial and credit activities: problems of theory and practice, 14, 175-182 [in Ukrainian].

16. Perebyinis, V. I., $\quad$ Fedirets, O. V., $\quad$ Perebyinis V. I. $\quad$ (2012). Enerhetychnyi faktor zabezpechennia konkurentospromozhnosti produktsii : monohrafiia [Energy factor of product competitiveness: monograph]. Poltava: PUET [in Ukrainian].

17. Gorbonos, F. V. (2010). Ekonomika pidpryiemstv : pidruchnyk [Economics of enterprises: textbook]. Kiev: Znanni., [in Ukrainian].

18. Zapukhlyak, I. B. (2011). Otsinka efektyvnosti funktsionuvannia mekhanizmu enerhozberezhennia pidpryiemstva [Estimation of efficiency of functioning of the mechanism of energy saving of the enterprise]. Teoretychni ta prykladni pytannia ekonomiky - Theoretical and applied issues of economics, 25, 179-184 [in Ukrainian].

19. Ginzburg, M. D. (2008). Terminolohichni problemy na shliakhu efektyvnoho vykorystannia palyvnoenerhetychnykh resursiv [Terminology. Terminological problems on the way to efficient use of fuel and energy resources]. Elektroinform - Elektroinform, 1, 54-55 [in Ukrainian].

20. Bevz, V. V. (2011). Rozvytok mekhanizmu enerhozberezhennia na pidpryiemstvakh kharchovoi promyslovosti [Development of energy saving mechanism at food industry enterprises. Scientific notes], 13, 169-173 [in Ukrainian]. 